Article

\title{
Antioxidant Potential of Grass Pea Seeds from European Countries
}

\author{
Wojciech Rybiński ${ }^{1}$, Magdalena Karamać ${ }^{2}{ }^{\mathbb{D}}$, Katarzyna Sulewska ${ }^{2}$, Andreas Börner ${ }^{3}$ and \\ Ryszard Amarowicz 2,* (D) \\ 1 Institute of Plant Genetics, Polish Academy of Sciences, Strzeszyńska 34, 60-479 Poznań, Poland; \\ wryb@igr.poznan.pl \\ 2 Institute of Animal Reproduction and Food Research, Polish Academy of Sciences, 10-748 Olsztyn, Poland; \\ m.karamac@pan.olsztyn.pl (M.K.); k.sulewska@pan.olsztyn.pl (K.S.) \\ 3 Leibniz Institute of Plant Genetics and Crop Plant Research, D-06466 Gatersleben, Germany; \\ boerner@ipk-gatersleben.de \\ * Correspondence: r.amarowicz@pan.olsztyn.pl; Tel.: +48-895-2346-27
}

Received: 6 July 2018; Accepted: 27 August 2018; Published: 1 September 2018

\begin{abstract}
Phenolic compounds were extracted from seeds of 30 varieties of grass pea (Lathyrus sativus) into $80 \%(v / v)$ methanol. The total phenolics compounds content of the extracts and their antioxidant activity were determined using Folin-Ciocalteu's phenol reagent and 2,2'-azinobis-(3-ethylbenzothi azoline-6-sulfonic acid) (ABTS) and ferric-reducing antioxidant power (FRAP) methods, respectively. Total phenolic contents ranged from 1.88 to $7.12 \mathrm{mg} / \mathrm{g}$ extract and 20.3 to $70.3 \mathrm{mg} / 100 \mathrm{~g}$ seeds. The extracts and seeds were characterized using Trolox equivalent antioxidant capacity values of $0.015-0.037 \mathrm{mmol}$ Trolox/g extract and $0.158-0.372 \mathrm{mmol}$ Trolox/100 g seeds, and FRAP values of $0.045-0.120 \mathrm{mmol} \mathrm{Fe}{ }^{2+} / \mathrm{g}$ extract and $0.487-1.189 \mathrm{Fe}^{2+} / 100 \mathrm{~g}$ seeds. The total phenolics content of grass pea extract was correlated with the results of the ABTS $(r=0.881)$ and FRAP $(r=0.781)$ assays. The same correlation was observed between the results of both assays $(r=0.842)$. Two derivatives of $p$-coumaric acid were the dominant phenolic compounds of the Derek cultivar of grass pea.
\end{abstract}

Keywords: grass pea; Lathyrus sativus; phenolic compounds; antioxidant activity

\section{Introduction}

Grass pea (Lathyrus sativus) is an ideal legume for resource-poor farmers, characterized by drought tolerance and thriving with minimal external inputs [1]. It is cultivated in the Indian subcontinent, Ethiopia, and to a lesser extent in North Africa, Australia, Asia, and Europe [2]. Currently, grass peas, similar to other legumes such as chickpea, lentil, and vetch are beginning to be cultivated in the Old World [3]. Grass pea seeds have a high nutritional value [4]. The protein, starch, lipids, mineral, and energy content in grass peas is similar to those of peas and faba beans [5]. For example, according to literature data, the protein content in grass pea, pea, and faba bean seeds is $26.5,20.6$, and $19-30 \mathrm{~g} / 100 \mathrm{~g}$, respectively [5-7]. The fatty acid profile of grass pea lipids is valuable. A high percentage of stearic acid was determined in grass pea lipids by Mehmet [8]. In epidemiologic and clinical studies, stearic acid was found to be associated with lowered low-density lipoprotein (LDL) cholesterol in comparison with other saturated fatty acids [9].

Unfortunately, grass pea seeds contain a neurotoxin, $\beta$ - $N$-oxalyl-1- $\alpha, \beta$-diamino-propionic acid ( $\beta$-ODAP). This non-protein amino acid causes neurolathyrism, a neurological disease in humans and domestic animals [10]. The $\beta$-ODAP content of traditional grass pea cultivars is $0.5-2.5 \%$. Genetic improvement of grass pea has reduced this content to $<0.10 \%$ [11]. Soaking and boiling considerably reduces the content of $\beta$-ODAP in grass pea seeds $[12,13]$. Grass pea seeds can be used as 
a high-value protein source after protein extraction and the removal of antinutritional components [14]. Suitable functional properties (water absorption capacity, oil absorption capacity, foaming capacity, and foaming stability) of grass pea proteins were reported by Aletor et al. [15].

Legumes are a potentially valuable crop with high antioxidant potential [16]. The antioxidant and antiradical activities of leguminous seed extracts have been investigated using a variety of methods including liposomes, enhanced chemiluminescence, a $\beta$-carotene-linoleate model system, 2,2'-diphenyl-1-picrylhydrazyl (DPPH) and 2,2'-azinobis-(3-ethylbenzothiazoline-6-sulfonic acid) ABTS assays, the reducing power assay, LDL cholesterol oxidation, ferric-reducing antioxidant power (FRAP) assay, $\mathrm{Fe}^{2+}$-chelating capacity assay, and the hydrophilic oxygen radical absorbance capacity $\left(\mathrm{ORAC}_{\mathrm{FL}}\right)$ assay [17].

The reported content of total phenolics of grass pea flour was 0.22 and $0.27 \mathrm{~g} / 100 \mathrm{~g}$ [18]. The phenolic content of grass pea extracts was correlated with their antioxidant properties determined using DPPH, FRAP, and $\beta$-carotene bleaching methods [19]. Menga et al. [20] reported linear correlations between the content of total phenolics, total flavonoids, and condensed tannins and results of the ABTS assay for grass pea extracts $(p<0.001)$. Total phenolic and condensed tannin levels were not correlated with seed yield and seed protein content in grass pea [21]. Grass peas extract inhibited $\alpha$-amylase and $\alpha$-glucosidase in an in vitro bioassay [19]. Results obtained by Stanisavljević et al. [22] strongly suggest that simple cooking treatment and in vitro digestion of grass pea seed flour applied prior to extraction with methanol could improve the antioxidative activity of the obtained extracts.

The present study aimed to determine the total phenolic content of grass pea extracts and seeds as well their antioxidant activity and potential. To the best of our knowledge, this is the first publication to consider such a broad biological material from several countries.

\section{Materials and Methods}

\subsection{Plant Material}

Plant material consisted of a collection of 30 grass pea varieties obtained in a field experiment conducted in Cerekwica $\left(51^{\circ} 55^{\prime} \mathrm{N}, 17^{\circ} 21^{\prime} \mathrm{E}\right)$ derived from Italian, Spanish, French, German, and Polish lines. Descriptors for Lathyrus sativus were used (IPGRI 2000) for the evaluation and characterization of the phenotypic features of the new lines. The growth habit of each line was recorded at $50 \%$ flowering and scored as prostrate, spreading, semi-erect or erect. Flower colors were scored as blue, pink, red, white, or various combination of these colours. Pod shapes were scored as oblong, medium, oblong elliptical, curved, broad, broad-linear/elliptical, or a combination of these shapes. Seed coat color and shape were recorded on 100 randomly selected seeds immediately after threshing. Seed shape was generally classified as angled or wedge-shaped. After harvest, 10 randomly selected plants from each accession were chosen for estimation of quantitative traits (yield structure parameters). The weight of 100 seeds was calculated from weighing and counting at least 200 seeds. Until extraction, the seeds were stored in a refrigerator closed in vacuum bags. The characteristics of those seeds are reported in Table 1.

Table 1. Characteristic of grass seeds investigated in this study.

\begin{tabular}{ccccc}
\hline No. & Accession Code & Country of Origin & Seeds Coat Color & Weight of 100 Seeds (g) \\
\hline 1 & LAT $4051 / 99$ & Italy & Cream to bright green & 37.8 \\
2 & LAT $4052 / 99$ & Italy & Cream to bright green & 42.6 \\
3 & LAT $4053 / 99$ & Italy & Cream to bright green & 28.2 \\
4 & LAT $4054 / 99$ & Italy & Cream, mottled with brown edge & 25.7 \\
5 & LAT $4055 / 99$ & Italy & Cream, slightly mottled and flattened & 46.5 \\
6 & LAT $4056 / 99$ & Italy & Green & 29.0 \\
7 & LAT $4061 / 99$ & Italy & Greyed-white with brown edge & 32.1 \\
8 & LAT $4063 / 01$ & Italy & Cream-white & 29.1 \\
9 & LAT $4064 / 01$ & Italy & Brick-red, dark mottled & 30.0 \\
\hline
\end{tabular}


Table 1. Cont.

\begin{tabular}{ccccc}
\hline No. & Accession Code & Country of Origin & Seeds Coat Color & Weight of 100 Seeds (g) \\
\hline 10 & LAT $4065 / 01$ & Italy & Greyed-white with brown edge & 24.9 \\
11 & LAT $4068 / 01$ & Italy & Brick-red, dark mottled & 29.4 \\
12 & LAT $4069 / 01$ & Italy & Cream slightly flattened & 30.4 \\
13 & LAT $4070 / 01$ & Italy & Brick-red, dark mottled & 24.7 \\
14 & LAT $4071 / 01$ & Italy & Cream & 20.1 \\
15 & LAT $4074 / 01$ & Italy & Greyed-white with brown edge & 30.0 \\
16 & LAT $4075 / 00$ & Italy & Cream with brown edge & 31.3 \\
17 & LAT $4078 / 00$ & Italy & Cream to bright green with brown edge & 48.0 \\
18 & LAT $4079 / 01$ & Italy & Cream with brown edge & 40.9 \\
19 & LAT $4081 / 00$ & Italy & Cream & 18.2 \\
20 & LAT $4082 / 00$ & Italy & Cream with brown edge & 21.4 \\
21 & LAT $456 / 75$ & Spain & Cream with dark edge & 28.5 \\
22 & LAT $1706 / 92$ & Spain & Cream with short black edge & 27.7 \\
23 & LAT $4006 / 84$ & Cream with brown edge & 23.5 \\
24 & LAT $4007 / 84$ & Spain & Cream & 25.3 \\
25 & LAT $4085 / 73$ & Spain & Cream & 26.1 \\
26 & LAT $444 / 73$ & Germany & Cream, brown edge, slightly mottled & 16,7 \\
27 & LAT 478 & Germany & Gray, dark brown edge, slightly mottled & 19.5 \\
28 & LAT 447 & France & Cream, slightly brick-red & 16.4 \\
29 & LAT 448 & France & Cream & 17.9 \\
30 & Cultivar Derek & Poland & Bridge-cream & 11.8 \\
\hline & LAT means "Lathyrus". Seed size (100 seeds): below 15 g: small; 15-25 g: medium, and above 25 g: large.
\end{tabular}

\subsection{Chemicals}

Sodium persulfate, ferrous chloride, Folin-Ciocalteau's phenol reagent, 2,2'-azinobis-(3-ethylben zothiazoline-6-sulfonic acid) (ABTS), 2,4,6-tri(2-pyridyl)-s-triazine (TPTZ), 6-hydroxy-2,5,7,8-tetrame thyl-chroman-2-carboxylic acid (Trolox), and (+)-catechin were purchased from Sigma (Poznań, Poland). Acetonitrile high-performance liquid chromatography (HPLC) grade and methanol were obtained from P.O.Ch. Company (Gliwice, Poland).

\subsection{Extraction}

Phenolic compounds were extracted from ground seeds using $80 \%(v / v)$ methanol at a solids to solvent ratio of 1:10 (w/v) for $15 \mathrm{~min}$ at $50{ }^{\circ} \mathrm{C}$ [23]. The extraction was repeated twice, the supernatants were filtered and combined, and methanol was evaporated under vacuum in a R-200 rotary evaporator (Büchi Labortechnik AG, Flawil, Switzerland). The remaining aqueous solution was lyophilized.

\subsection{Total Phenolic Compounds Content}

The method described by Naczk and Shahidi [24] was used to determine the total phenolic compounds content of the extracts. Briefly, a $0.5-\mathrm{mL}$ aliquot of seed extract dissolved in methanol was pipetted into a test tube containing $8 \mathrm{~mL}$ distilled water. After mixing the contents, $0.5 \mathrm{~mL}$ Folin-Ciocalteu's phenol reagent and $1 \mathrm{~mL}$ saturated sodium carbonate solution were added. The contents were vortexed for $15 \mathrm{~s}$ and then left to stand at room temperature for $30 \mathrm{~min}$. Absorbance measurements were recorded at $725 \mathrm{~nm}$ using a Beckman DU 7500 Spectrophotometer (Beckman Poland, Warsaw, Poland). Estimation of the phenolic compounds was carried out in triplicate. The results are expressed as (+)-catechin equivalents per $\mathrm{g}$ of the extract or $100 \mathrm{~g}$ seeds.

\subsection{Condensed Tannins}

Condensed tannins were determined using a vanillin/HCL colorimetric method [25]. The results obtained are reported as absorbance units at $500 \mathrm{~nm}$ per $1 \mathrm{mg}$ extract. 


\subsection{ABTS Assay}

The Trolox equivalent antioxidant capacity (TEAC) was determined using a method described by Re et al. [26]. Here, $\mathrm{ABTS}^{+}$solution was prepared by mixing an ABTS stock solution in water with $2.45 \mathrm{mM}$ sodium persulphate. This mixture was allowed to stand with shaking for $12-16 \mathrm{~h}$ at room temperature in the dark until reaching a stable oxidative state. For analysis, the $\mathrm{ABTS}^{+}$stock solution was diluted with methanol to an absorbance of 0.720 at $734 \mathrm{~nm}$. For the spectrophotometric assay, $2 \mathrm{~mL}$ $\mathrm{ABTS}^{+}$reagent and $20 \mu \mathrm{L}$ plant extract were mixed and the absorbance was read at $734 \mathrm{~nm}$ at $37^{\circ} \mathrm{C}$ for $10 \mathrm{~min}$. A calibration curve was plotted using Trolox standard solution. The results are expressed as mmol Trolox equivalent per $\mathrm{g}$ extract or $100 \mathrm{~g}$ seeds.

\subsection{Ferric-Reducing Antioxidant Power (FRAP) Assay}

The ferric-reducing antioxidant power (FRAP) assay was performed as previously described by Benzie and Strain [27]. The sample solution was first diluted with deionized water to fit within the linearity range. The working FRAP reagent was prepared by mixing 10 volumes of $300 \mathrm{mM}$ acetate buffer, $\mathrm{pH}$ 3.6, with 1 volume of $10 \mathrm{mM}$ TPTZ in $40 \mathrm{mM} \mathrm{HCL}$, and with 1 volume of $20 \mathrm{mM} \mathrm{FeCl}_{3}$ $\times 6 \mathrm{H}_{2} \mathrm{O}$. A volume of $2.25 \mathrm{~mL}$ of a working FRAP reagent was warmed to $37^{\circ} \mathrm{C}$. Then, $75 \mu \mathrm{L}$ of the sample and $225 \mu \mathrm{L}$ of deionized water were added to the FRAP reagent and the absorbance was measured at $593 \mathrm{~nm}$ against a reagent blank after $30 \mathrm{~min}$ incubation. The FRAP values were calculated and are expressed as mmol of $\mathrm{Fe}^{2+}$ equivalent per g extract or $100 \mathrm{~g}$ of seeds.

\subsection{HPLC Analysis}

Methanolic extract $(20 \mathrm{mg}$ ) of Derek cultivar was dissolved in $2 \mathrm{~mL}$ of $80 \%$ methanol and filtered through a $0.45 \mu \mathrm{m}$ cellulose acetate filter (Millipore, Warsaw, Poland). Phenolic compounds were analysed using a Shimadzu HPLC system (Shimadzu Corp., Kyoto, Japan) consisting of two LC-10AD pumps, a SCTL 10A system controller, and a SPD-M 10A photodiode array detector. The chromatography was performed using a pre-packed Luna C18 column $(4 \times 250 \mathrm{~mm}, 5 \mu \mathrm{m}$; Phenomenex, Torrance, CA, USA). Elution proceeded for $50 \mathrm{~min}$ in a gradient system of $5-40 \%$ acetonitrile in water adjusted to $\mathrm{pH} 2.5$ with trifluoroacetic acid (TFA) [28]; the detector was set at 320, the injection volume was $20 \mu \mathrm{L}$, and the flow rate was $1 \mathrm{~mL} / \mathrm{min}$.

\subsection{Statistical Analysis}

The results obtained in this study are reported as the mean values of three estimates \pm standard deviation. Pearson correlation was used to determine the relationship between total phenolics content, TEAC, and FRAP. Principal component analysis (PCA) and hierarchical cluster analysis (HCA) with Ward's method using Euclidean distances were also used. Statistical and chemometric data analyses were performed using Statistica (Windows software package 8.0, Dell Inc., Tulsa, OK, USA).

\section{Results and Discussion}

\subsection{Content of Total Phenolics Compounds}

The total phenolics contents of the extracts were determined using a Folin-Ciocalteu's phenol reagent. The results are expressed as (+)-catechin equivalents per $\mathrm{g}$ of the extract or $100 \mathrm{~g}$ seeds (Table 2). The total phenolic content ranged from 1.88 (LAT 4065/01) to $7.12 \mathrm{mg} / \mathrm{g}$ extract (LAT 4054/99) and from 20.3 (LAT 4065/01) to $70.3 \mathrm{mg} / 100 \mathrm{~g}$ seeds (LAT 4065/01). These concentrations are low and can be compared to those obtained previously for white bean [28] and pea [16]. Very similar total phenolic contents (20.6 and $21.3 \mathrm{mg} / 100 \mathrm{~g}$ ) were reported by Fratianni et al. [29] in two Italian varieties of grass pea, and by Wang et al. [21].in nine varieties of Canadian grass pea $(16.2-37.5 \mathrm{mg} / 100 \mathrm{~g})$. Higher total phenolic compounds contents in grass pea were reported by Wiszniewska and Piwowarczyk [30] and Carbonaro et al. [18]. 
Table 2. Characteristics of the grass pea seeds and their extracts: content of total phenolics and antioxidant activity.

\begin{tabular}{|c|c|c|c|c|c|c|}
\hline \multirow[b]{2}{*}{ No. } & \multicolumn{2}{|c|}{ Total Phenolics ${ }^{1}$} & \multicolumn{2}{|c|}{ ABTS $^{2}$ Assay } & \multicolumn{2}{|c|}{ FRAP $^{3}$ Assay } \\
\hline & mg/g Extract & mg/100 g Seeds & mmol TE/g Extract & $\begin{array}{c}\text { mmol TE/100 g } \\
\text { Seeds }\end{array}$ & $\begin{array}{c}\mathrm{mmol} \mathrm{Fe}^{2+} / \mathrm{g} \\
\text { Extract }\end{array}$ & $\begin{array}{c}\text { mmol } \mathrm{Fe}^{2+} / 100 \mathrm{~g} \\
\text { Seeds }\end{array}$ \\
\hline 1 & $3.49 \pm 0.07$ & $40.6 \pm 0.8$ & $0.015 \pm 0.000$ & $0.170 \pm 0.001$ & $0.074 \pm 0.001$ & $0.859 \pm 0.009$ \\
\hline 2 & $3.85 \pm 0.04$ & $41.6 \pm 0.4$ & $0.020 \pm 0.000$ & $0.214 \pm 0.001$ & $0.080 \pm 0.002$ & $0.861 \pm 0.021$ \\
\hline 3 & $2.63 \pm 0.03$ & $30.5 \pm 0.4$ & $0.016 \pm 0.000$ & $0.186 \pm 0.003$ & $0.061 \pm 0.001$ & $0.713 \pm 0.017$ \\
\hline 4 & $7.12 \pm 0.10$ & $73.0 \pm 1.1$ & $0.037 \pm 0.001$ & $0.372 \pm 0.014$ & $0.120 \pm 0.001$ & $1.028 \pm 0.012$ \\
\hline 5 & $3.12 \pm 0.04$ & $36.1 \pm 0.4$ & $0.022 \pm 0.000$ & $0.253 \pm 0.001$ & $0.073 \pm 0.002$ & $0.851 \pm 0.021$ \\
\hline 6 & $2.40 \pm 0.03$ & $27.2 \pm 0.4$ & $0.016 \pm 0.000$ & $0.176 \pm 0.001$ & $0.058 \pm 0.001$ & $0.654 \pm 0.010$ \\
\hline 7 & $3.66 \pm 0.04$ & $48.2 \pm 0.5$ & $0.018 \pm 0.000$ & $0.241 \pm 0.003$ & $0.059 \pm 0.001$ & $0.780 \pm 0.015$ \\
\hline 8 & $3.68 \pm 0.02$ & $41.6 \pm 0.2$ & $0.019 \pm 0.000$ & $0.210 \pm 0.004$ & $0.059 \pm 0.001$ & $0.662 \pm 0.004$ \\
\hline 9 & $6.35 \pm 0.10$ & $65.5 \pm 1.0$ & $0.031 \pm 0.001$ & $0.319 \pm 0.0013$ & $0.115 \pm 0.001$ & $1.189 \pm 0.008$ \\
\hline 10 & $1.88 \pm 0.07$ & $20.3 \pm 0.8$ & $0.015 \pm 0.000$ & $0.232 \pm 0.002$ & $0.045 \pm 0.003$ & $0.487 \pm 0.002$ \\
\hline 11 & $3.97 \pm 0.17$ & $41.6 \pm 1.8$ & $0.022 \pm 0.000$ & $0.158 \pm 0.002$ & $0.084 \pm 0.002$ & $0.889 \pm 002$ \\
\hline 12 & $1.99 \pm 0.05$ & $22.1 \pm 0.6$ & $0.017 \pm 0.000$ & $0.191 \pm 0.004$ & $0.101 \pm 0.002$ & $0.557 \pm 0.008$ \\
\hline 13 & $5.68 \pm 0.10$ & $61.8 \pm 1.1$ & $0.033 \pm 0.001$ & $0.229 \pm 0.002$ & $0.069 \pm 0.002$ & $1.105 \pm 0.002$ \\
\hline 14 & $4.11 \pm 0.09$ & $42.4 \pm 0.9$ & $0.026 \pm 0.001$ & $0.232 \pm 0.002$ & $0.069 \pm 0.001$ & $0.707 \pm 0.024$ \\
\hline 15 & $4.45 \pm 0.07$ & $45.0 \pm 0.7$ & $0.031 \pm 0.001$ & $0.309 \pm 0.002$ & $0.083 \pm 0.002$ & $0.835 \pm 0.018$ \\
\hline 16 & $3.94 \pm 0.03$ & $38.6 \pm 0.3$ & $0.023 \pm 0.000$ & $0.225 \pm 0.002$ & $0.074 \pm 0.001$ & $0.724 \pm 0.006$ \\
\hline 17 & $3.24 \pm 0.03$ & $37.4 \pm 0.4$ & $0.020 \pm 0.000$ & $0.229 \pm 0.001$ & $0.063 \pm 0.002$ & $0.728 \pm 0.021$ \\
\hline 18 & $4.18 \pm 0.07$ & $47.2 \pm 0.7$ & $0.020 \pm 0.000$ & $0.227 \pm 0.001$ & $0.062 \pm 0.002$ & $0.698 \pm 0.021$ \\
\hline 19 & $5.37 \pm 0.07$ & $56.8 \pm 0.7$ & $0.025 \pm 0.001$ & $0.263 \pm 0.004$ & $0.073 \pm 0.001$ & $0.769 \pm 0.006$ \\
\hline 20 & $4.84 \pm 0.03$ & $49.5 \pm 0.7$ & $0.028 \pm 0.001$ & $0.284 \pm 0.006$ & $0.073 \pm 0.001$ & $0.740 \pm 0.012$ \\
\hline 21 & $3.27 \pm 0.04$ & $35.7 \pm 0.4$ & $0.016 \pm 0.000$ & $0.179 \pm 0.001$ & $0.060 \pm 0.003$ & $0.524 \pm 0.030$ \\
\hline 22 & $4.24 \pm 0.07$ & $46.9 \pm 0.8$ & $0.024 \pm 0.001$ & $0.269 \pm 0.001$ & $0.062 \pm 0.001$ & $0.678 \pm 0.09$ \\
\hline 23 & $4.55 \pm 0.07$ & $48.0 \pm 0.3$ & $0.022 \pm 0.000$ & $0.230 \pm 0.004$ & $0.060 \pm 0.001$ & $0.655 \pm 0.010$ \\
\hline 24 & $3.50 \pm 0.04$ & $36.9 \pm 0.3$ & $0.019 \pm 0.000$ & $0.196 \pm 0.003$ & $0.053 \pm 0.002$ & $0.557 \pm 0.018$ \\
\hline 25 & $2.45 \pm 0.03$ & $37.4 \pm 0.5$ & $0.016 \pm 0.000$ & $0.180 \pm 0.003$ & $0.059 \pm 0.002$ & $0.687 \pm 0.030$ \\
\hline 26 & $4.40 \pm 0.06$ & $41.4 \pm 0.7$ & $0.021 \pm 0.000$ & $0.212 \pm 0.004$ & $0.062 \pm 0.002$ & $0.622 \pm 0.024$ \\
\hline 27 & $4.82 \pm 0.10$ & $59.1 \pm 0.7$ & $0.027 \pm 0.001$ & $0.293 \pm 0.006$ & $0.062 \pm 0.003$ & $0.683 \pm 0.028$ \\
\hline 28 & $2.49 \pm 0.07$ & $49.7 \pm 0.3$ & $0.020 \pm 0.000$ & $0.205 \pm 0.007$ & $0.070 \pm 0.003$ & $0.723 \pm 0.031$ \\
\hline 29 & $4.77 \pm 0.11$ & $32.5 \pm 0.4$ & $0.025 \pm 0.001$ & $0.244 \pm 0.004$ & $0.066 \pm 0.001$ & $0.659 \pm 0.010$ \\
\hline 30 & $2.26 \pm 0.02$ & $41.3 \pm 0.7$ & $0.019 \pm 0.000$ & $0.180 \pm 0.001$ & $0.065 \pm 0.001$ & $0.638 \pm 0.007$ \\
\hline
\end{tabular}

\subsection{Content of Condensed Tannins}

The extracts obtained from samples 5, 10, 12, 16, 17, 21, 22, 23, and 28 contained small amounts of condensed tannins. The results expressed as absorbance at $500 \mathrm{~nm}$ per $\mathrm{mg}$ extract ranged from 0.001 to 0.004. The contents of condensed tannins reported previously for extracts of lentil, abzuki bean, faba bean, broad bean, and red bean were much higher [16].

\subsection{Antioxidant Activity}

The results of the ABTS and FRAP assays are presented in Table 2. The extracts and seeds were characterized by the Trolox equivalent antioxidant capacity (TEAC) values, ranging from 0.015 (LAT 4051/99 and LAT 4065/01) to $0.037 \mathrm{mmol}$ Trolox/g extract (LAT 4054/99) and from 0.158 (LAT 4068/01) to $0.372 \mathrm{mmol}$ Trolox/100 g seeds (LAT 4054/99). Ferric-reducing antioxidant power (FRAP) values varied from 0.045 (LAT 4065/01) to $0.120 \mathrm{mmol} \mathrm{Fe}^{2+} / \mathrm{g}$ extract (LAT 4054/99) and from 0.487 (LAT 4068/01) to $1.189 \mathrm{Fe}^{2+} / 100 \mathrm{~g}$ seeds (LAT 4054/99). The results were compared to those reported previously for white bean $[16,23]$. Some papers reported the antioxidant capacity of grass pea seeds or their extracts determined using DPPH, ABTS, and FRAP assays, $\beta$-carotene bleaching, and $\mathrm{H}_{2} \mathrm{O}_{2}$ scavenge [22,31-33]. In general, the results were lower relative to the results reported for other leguminous seeds. For example, extracts of cow pea were characterised by TEAC and TRAP values of $0.285-0.665 \mathrm{TE} / \mathrm{g}$ extract and $0.487-1.560 \mathrm{mmol} \mathrm{Fe}^{2+} / \mathrm{g}$ extract [34].

\subsection{HPLC Analysis}

The phenolic compounds contained in grass pea of the Derek cultivar were separated by HPLC, and the resulting chromatogram showed the presence of two major peaks ( 1 and 2) with retention 
times of 20.5 and $26.4 \mathrm{~min}$, respectively (Figure 1). The UV-diode array detector (UV-DAD) spectra of compound 1 were characterized by maxima at $309 \mathrm{~nm}$ and were very similar to the spectrum of $p$-coumaric acid (Figure 2). The contents of compounds 1 and 2 in the extract and seeds of Derek cultivar are reported in Table 3. The presence of $p$-coumaric acid and its derivatives have been reported for lentil, broad bean, adzuki bean, and faba bean [35-38]. The high content of $p$-coumaric acid in grass pea was reported by Carbonaro et al. [18].

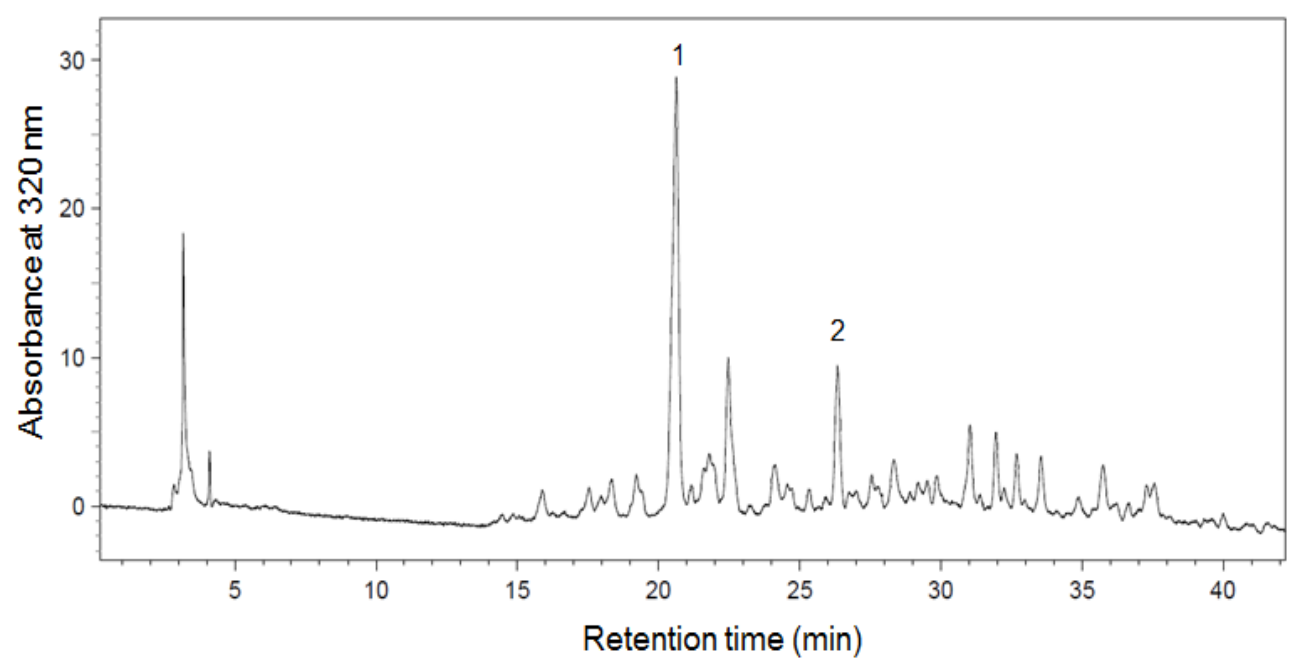

Figure 1. High performance liquid chromatography (HPLC) chromatogram of Lathyrus sativus Derek cultivar extract.
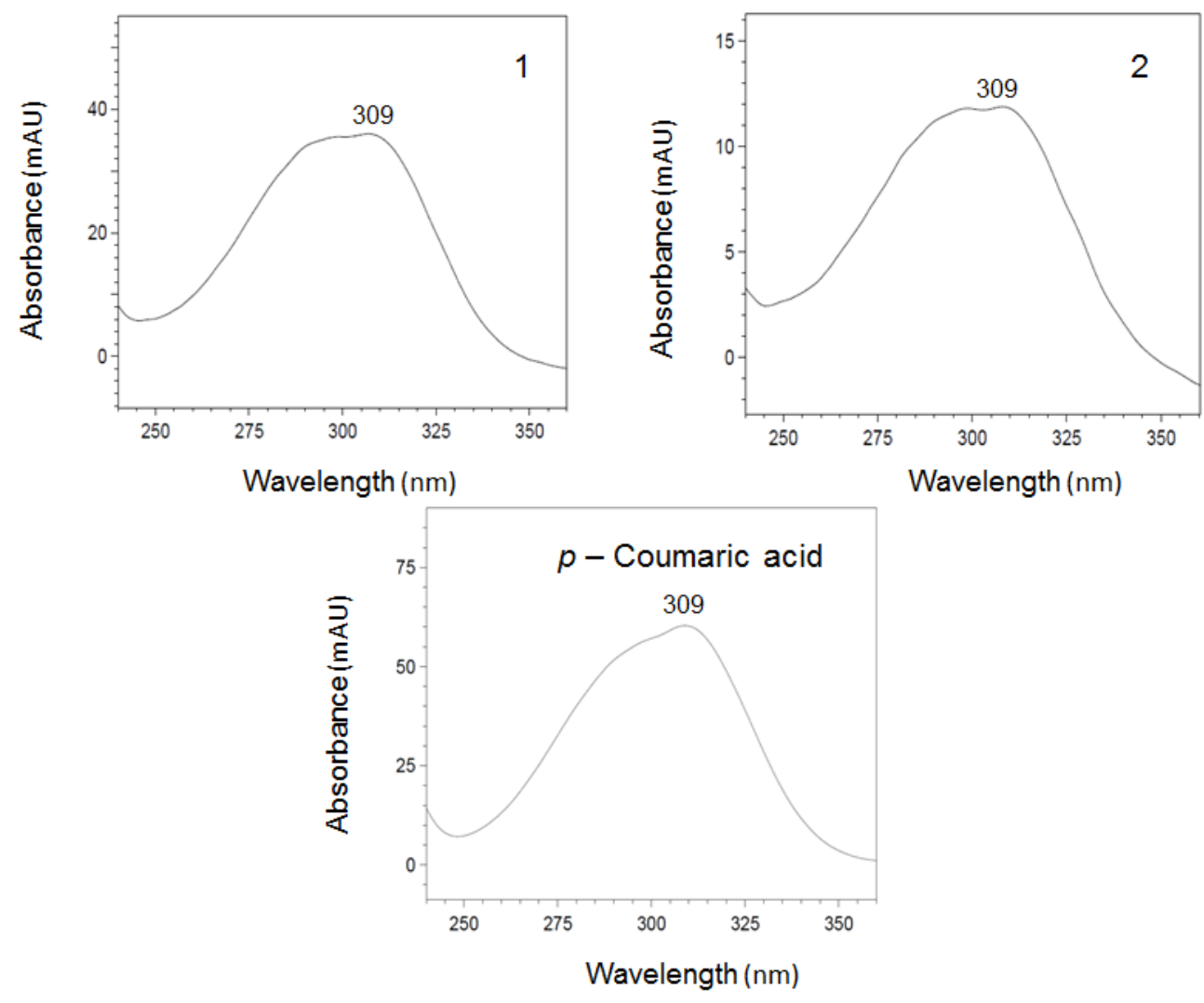

Figure 2. UV-diode array detector (UV-DAD) spectra of compound 1 and 2 separated using HPLC method and standard of $p$-coumaric acid. 
Table 3. Content of two main phenolic compounds in Derek cultivar of grass pea.

\begin{tabular}{ccc}
\hline \multirow{2}{*}{ Phenolic Compound } & \multicolumn{2}{c}{ Content $^{\mathbf{1}}$} \\
\cline { 2 - 3 } & $\mathbf{m g} / \mathbf{g}$ Extract & $\mathbf{~ m g / g ~ 1 0 0 ~ g ~ S e e d s ~}$ \\
\hline 1 & $1.15 \pm 0.05$ & $20.7 \pm 2.7$ \\
2 & $0.48 \pm 0.03$ & $8.64 \pm 0.54$ \\
\hline \multicolumn{3}{c}{${ }^{1} p$-coumaric acid equivalents. }
\end{tabular}

\subsection{Statistical Analysis}

In this work, for the first time, a correlation was calculated between the content of phenolic compounds in the grass pea extracts and their antioxidant activity. The correlation coefficients between the total phenolics content and the results of the ABTS and FRAP assays were 0.881 and 0.781 , respectively. This correlation was also observed in the results of both assays $(r=0.842)$ (Figure 3). A similar relationship between the content of total phenolics in leguminous extracts and their antioxidant activities was previously reported by Amarowicz et al. [39] and Orac et al. [28,40].

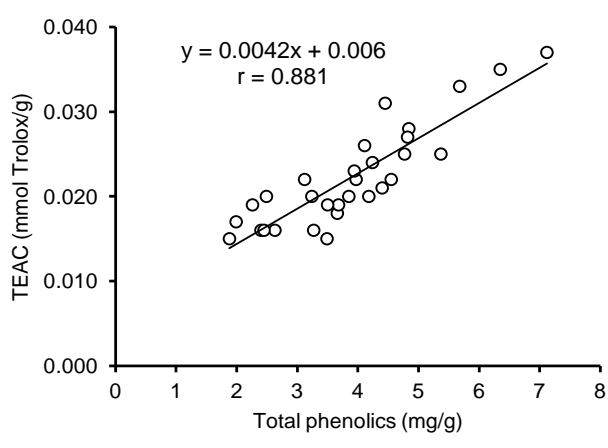

(a)

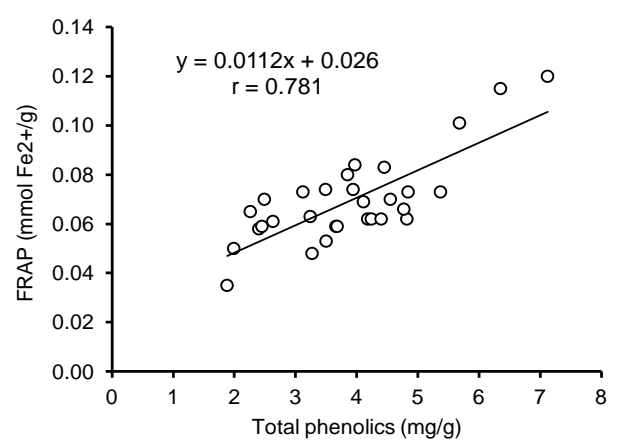

(b)

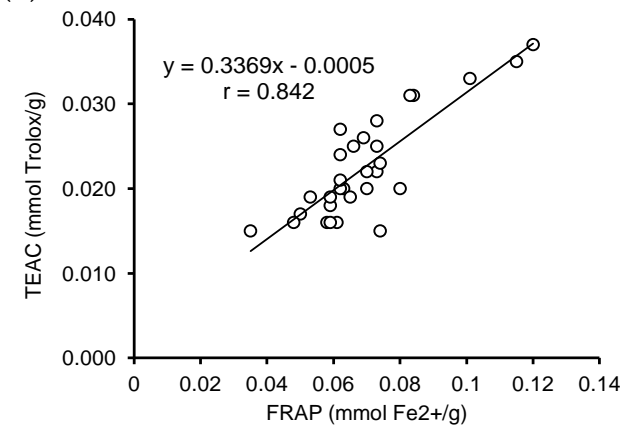

(c)

Figure 3. Correlation between (a) the total phenolics content and the results of 2,2'-azinobis-(3-ethylb enzothiazoline-6-sulfonic acid) (ABTS) assay, (b) total phenolics content and the results of the ferric-reducing antioxidant power (FRAP) assay, and (c) results of the two antioxidant assays.

In the principal component analysis (PCA) (Figure 4), the two first components accounted for $90.3 \%$ of the total variability between the grass pea varieties. The considerable variability in terms of the analyzed traits expressed jointly with the greatest Mahalanobis distance was recorded for Italian samples 3, 4, 9, 10, and 13 (LAT 4053/99, LAT 4054/99, LAT 4064/01, LAT 4065/01, and LAT 4070/01, respectively). According to Figure 2, discrimination of the sample geographical origin by PCA was rather difficult. 


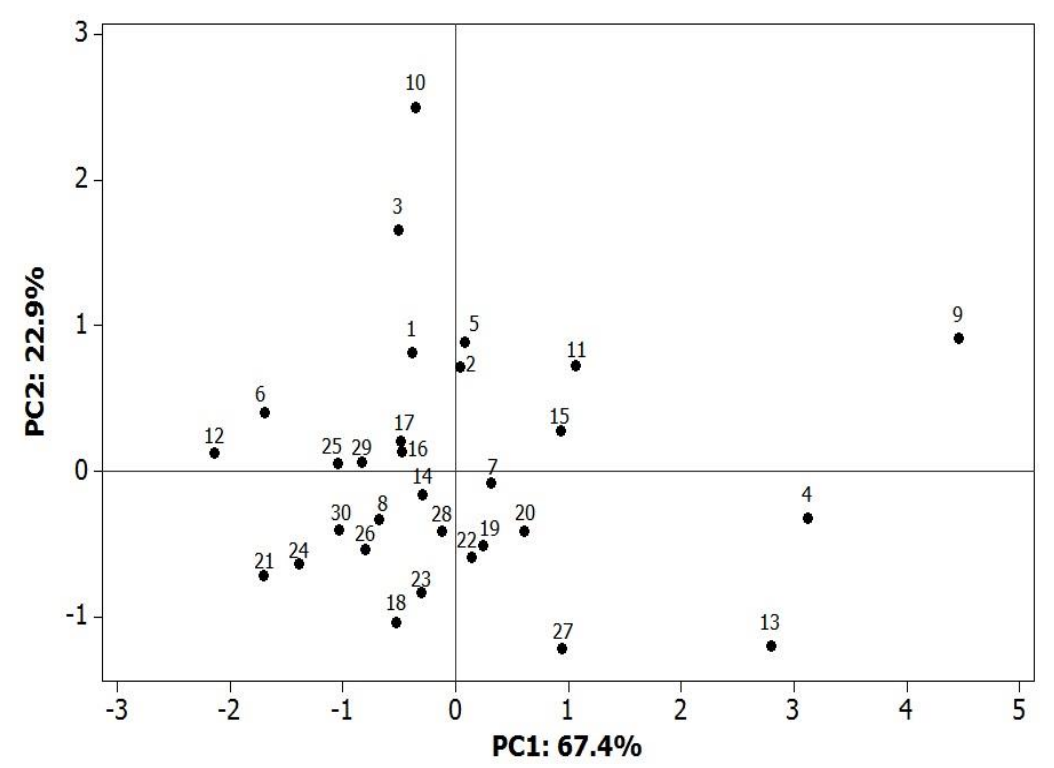

Figure 4. Results of the principal component analysis (PCA).

The hierarchical cluster analysis (Figure 5) shows several pairs of grass pea accessions (e.g., LAT 4053/99 and LAT 448; LAT 4061/01 and LAT 4006/84). Several of these pairs are, in turn, similar to each other (e.g., pair LAT 4061/01 and LAT 4006/84 and pair LAT 4063/10 and LAT 1706/92), whereas LAT 4054/99 is entirely different from all the others. The presence of similar pairs of grass peas accessions from different countries confirms the limitation of the hierarchical cluster analysis for the discrimination of the sample geographical origin.

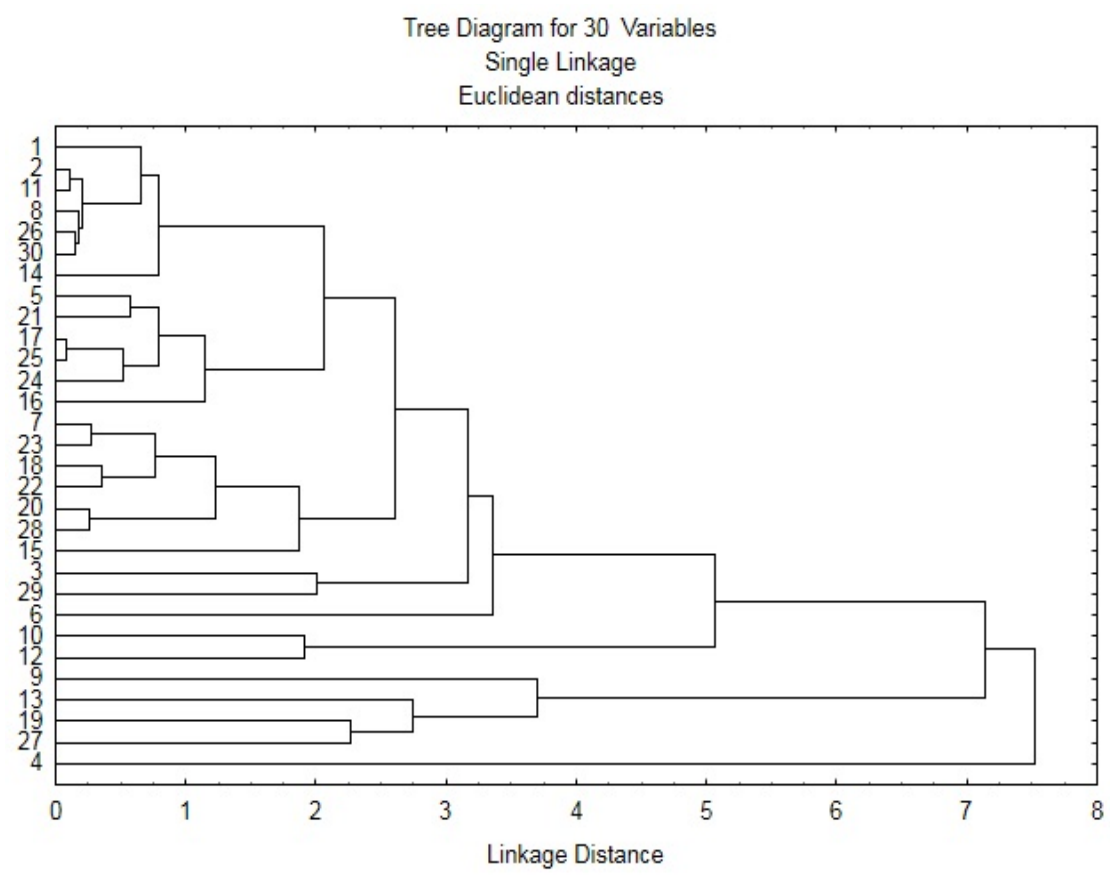

Figure 5. The hierarchical cluster analysis.

\section{Conclusions}

Grass pea seeds with reduced content of $\beta$-ODAP after technological processing can be a source of phenolic compounds in a vegetarian or vegan diet, and in the general population. The contents of 
total phenolics in grass pea extract are correlated, as demonstrated by the results of the ABTS and FRAP assays. The correlation was also observed between results of both assays. Two derivatives of $p$-coumaric acid were the dominant phenolic compounds of the Derek cultivar of grass pea. In future studies, the bioavailability of grass pea phenolic compounds will be investigated in vitro.

Author Contributions: W.R. Conceptualization, produced and contributed plant material, wrote the study; M.K. Performed the statistical analysis and wrote the study; K.S. Formal analysis; A.B. Produced and contributed plant material; R.A. Conceptualization and wrote the study.

Funding: This research received no external funding.

Acknowledgments: The technical assistance of Kamila Penkacik is acknowledged.

Conflicts of Interest: The authors declare no conflict of interest.

\section{References}

1. Hillocks, R.J.; Maruthi, M.N. Grass pea (Lathyrus sativus): Is there a case for further crop improvement? Euphytica 2012, 186, 647-654. [CrossRef]

2. Hanbury, C.D.; White, C.L.; Mullan, B.P.; Siddique, K.H.M. A review of the potential of Lathyrus sativus L. and L. cicera L. grain for use as animal feed. Anim. Feed Sci. Technol. 2000, 87, 1-27. [CrossRef]

3. Mikić, A.; Mihailović, V.; Ćupina, B.; Ethurić, B.; Krstić, D.; Vasić, M.; Vasiljević, S.; Karagi, D.; Dorthević, V. Towards the re-introduction of grass pea (Lathyrus sativus) in the West Balkan countries: The case of Serbia and Srpska (Bosnia and Herzegovina). Food Chem. Toxicol. 2011, 49, 650-654.

4. Ennenking, D. The nutritive value of grass pea (Lathyrus sativus) and allied species, their toxicity to animals and the role of malnutrition in neurolathyrism. Food Chem. Toxicol. 2011, 49, 694-709. [CrossRef] [PubMed]

5. Mullan, B.P.; Pluske, J.R.; Trezona, M.; Harris, D.J.; Allen, J.G.; Siddique, K.H.M.; Hanbury, C.D.; van Barneveld, R.J.; Kim, J.C. Chemical composition and standardised ileal digestible amino acid contents of Lathyrus (Lathyrus cicera) as an ingredient in pig diets. Anim. Feed Sci. Technol. 2009, 150, 139-143. [CrossRef]

6. Wozniak, A.; Soroka, M.; Stepniowska, A. Chemical composition of pea (Pisum sativum L.) seeds depending on tillage systems. J. Elementol. 2014, 14, 1143-1152. [CrossRef]

7. Kumar, A.; Nidhi, P.; Sinha, S.K. Nutritional and antinutritional attributes of faba bean (Vicia faba L.) germ plasms growing in Bihar, India. Physiol. Mol. Biol. Plants 2015, 21, 159-162. [CrossRef] [PubMed]

8. Mehmet, A. Fatty acid characteristics of grass pea (Lathyrus sativus) in an East Mediterranean environment. Cogent Chem. 2017, 3. [CrossRef]

9. Hunter, J.E.; Zhang, J.; Kris-Etherton, P.M. Cardiovascular disease risk of dietary stearic acid compared with trans, other saturated, and unsaturated fatty acids: A systematic review. Am. J. Clin. Nutr. 2009, 91, 46-63. [CrossRef] [PubMed]

10. Getahun, H.; Lambein, F.; Vanhoorne, M.; Van der Stuyft, P. Pattern and associated factors of the neurolathyrism epidemic in Ethiopia. Trop. Med. Int. Health 2002, 7, 118-124. [CrossRef] [PubMed]

11. Kumar, S.; Bejiga, G.; Ahmed, S.; Nakkoul, H.; Sarker, A. Genetic improvement of grass pea for low neurotoxin ( $\beta$-ODAP) content. Food Chem. Toxicol. 2011, 49, 589-600. [CrossRef] [PubMed]

12. Khandare, A.L.; Kumar, R.H.; Meshram, I.I.; Arlappa, N.; Laxmaiah, A.; Venkaiah, K.; Rao, P.A.; Validandi, V.; Toteja, G.S. Current scenario of consumption of Lathyrus sativus and lathyrism in three districts of Chhattisgarh State, India. Toxicon 2018, 150, 228-234. [CrossRef] [PubMed]

13. Srivastava, S.; Khokhar, S. Effect of processing on the reduction of $\beta$-ODAP ( $\beta$-N-Oxalyl-L-2,3-diaminopropionic acid) and anti-nutrients of khesari dhal, Lathyrus sativus. J. Sci. Food Agric. 1996, 71, 50-58. [CrossRef]

14. Pastor-Cavada, E.; Jua, R.; Pastor, J.E.; Alai, M.; Vioque, J. Protein isolates from two Mediterranean legumes: Lathyrus clymenum and Lathyrus annuus. Chemical composition, functional properties and protein characterization. Food Chem. 2010, 122, 533-538. [CrossRef]

15. Aletor, O.; Onyemem, C.E.; Aletor, V.A. Nutrient constituents, functional attributes and in vitro protein digestibility of the seeds of the Lathyrus plant. WIT Trans. Ecol. Environ. 2011, 152, 145-155. [CrossRef]

16. Amarowicz, R.; Pegg, R.B. Legumes as a source of natural antioxidants. Eur. J. Lipid Sci. Technol. 2008, 110, 865-878. [CrossRef] 
17. Vaz Patto, M.C.; Amarowicz, R.; Aryee, A.N.A.; Boye, J.I.; Chung, H.-J.; Martín-Cabrejas, M.A.; Domoney, C. Achievements and challenges in improving the nutritional quality of food legumes. Crit. Rev. Plant. Sci. 2015, 34, 105-143. [CrossRef]

18. Carbonaro, M.; Nardini, M.; Maselli, P.; Nucara, A. Chemico-physical and nutritional properties of traditional legumes (lentil, Lens culinaris L., and grass pea, Lathyrus sativus L.) from organic agriculture: An explorative study. Org. Agric. 2015, 5, 179-292. [CrossRef]

19. Talukdar, D. Antioxidant potential and type II diabetes related enzyme inhibition properties of raw and processed legumes in Indian Himalayas. J. Appl. Pharm. Sci. 2013, 3, 13-19. [CrossRef]

20. Menga, V.; Codianni, P.; Fares, C. Agronomic management under organic farming may affect the bioactive compounds of lentil (Lens culinaris L.) and grass pea (Lathyrus communis L.)? Sustainability 2014, 6, 1059-1075. [CrossRef]

21. Wang, X.; Warkentin, T.D.; Briggs, C.J.; Granese, T.; Albanese, D.; Di Matteo, M.; Zaccardelli, M.; Campbell, C.G.; Woods, S. Total phenolics and condensed tannins in field pea (Pisum sativum L.) and grass pea (Lathyrus sativus L.). Euphytica 1998, 101, 97-102. [CrossRef]

22. Stanisavljević, N.; Jovanović, Z.; Čupić, T.; Lukić, J.; Miljuš Dukić, M.J.; Radović, S.; Mikić, A. Extractability of antioxidants from legume seed flour after cooking and in vitro gastrointestinal digestion in comparison with methanolic extraction of the unprocessed flour. Int. J. Food Sci. Technol. 2013, 48, 2096-2104.

23. Amarowicz, R.; Raab, B. Antioxidative activity of leguminous seed extracts evaluated by chemiluminescence methods. Z. Naturforsch. 1997, 52, 709-712. [CrossRef]

24. Naczk, M.; Shahidi, F. The effect of methanol-ammonia-water treatment on the content of phenolic acids of canola. Food Chem. 1989, 31, 159-164. [CrossRef]

25. Price, M.L.; van Scoyoc, S.; Butler, L.G. A critical evaluation of the vanillin reaction as an assay for tannin in sorghum grain. J. Agric. Food Chem. 1978, 26, 1214-1218. [CrossRef]

26. Re, R.; Pellegrini, N.; Proteggente, A.; Pannala, A.; Yang, M.; Rice-Evans, C. Antioxidant activity applying an improved ABTS radical cation decolorization assay. Free Rad. Biol. Med. 1999, 26, 1231-1237. [CrossRef]

27. Benzie, I.E.F.; Strain, J.J. Ferric reducing/antioxidant power assay: Direct measure of total antioxidant activity of biological fluids and modified version for simultaneous measurement of total antioxidant power and ascorbic acid concentration. Methods Enzymol. 1990, 299, 15-27.

28. Orak, H.-H.; Karamać, M.; Orak, A.; Amarowicz, R. Aantioxidant potential and phenolic compounds of some widely consumed Turkish white bean (Phaseolus vulgaris L.) varieties. Pol. J. Food Nutr. Sci. 2016, 66, 253-260. [CrossRef]

29. Fratianni, F.; Cardinale, F.; Cozzolino, A.; Granese, T.; Albanese, D.; Di Matteo, M.; Zaccardelli, M.; Coppola, R.; Nazzaro, F. Polyphenol composition and antioxidant activity of different grass pea (Lathyrus sativus), lentils (Lens culinaris), and chickpea (Cicer arietinum) ecotypes of the Campania region (Southern Italy). J. Funct. Foods 2014, 7, 551-557. [CrossRef]

30. Wiszniewska, A.; Piwowarczyk, B. Activity of selected components of antioxidant system in grass pea and yellow lupine protoplasts after enzymatic isolation. Biotechnologia 2015, 96, 285-292. [CrossRef]

31. Talukdar, D. Total flavonoids, phenolics, tannins and antioxidant activity in seeds of lentil and grass pea. Int. J. Phytomed. 2012, 4, 2096-2104.

32. Tamburino, R.; Guida, V.; Pacifico, S.; Rocco, M.; Zarelli, A.; Parente, A.; Di Maro, A. Nutritional values and radical scavenging capacities of grass pea (Lathyrus sativus L.) seeds in Valle Agricola district, Italy. Austr. J. Crop. Sci. 2012, 6, 149-156.

33. Starzyńska-Janiszewska, A.; Stodolak, B. Effect of inoculated lactic acid fermentation on antinutritional and antiradical properties of grass pea (Lathyrus sativus "Krab") flour. Pol. J. Food Nutr. Sci. 2011, 61, 245-249. [CrossRef]

34. Siddhuraju, P.; Becker, K. The antioxidant and free radical scavenging activities of processed cowpea (Vigna unuguiculata (L.) Walp.) seed extracts. Food Chem. 2007, 101, 10-19. [CrossRef]

35. Amarowicz, R.; Shahidi, F. Antioxidant activity of broad bean seed extract and its phenolic composition. J. Funct. Foods 2017, 38, 656-662. [CrossRef]

36. Amarowicz, R.; Shahidi, F. Antioxidant activity of faba bean extract and fractions thereof. J. Food Bioact. 2018, 1, 112-118. [CrossRef]

37. Amarowicz, R.; Estrella, I.; Hernández, T.; Troszyńska, A. Antioxidant activity of extract of adzuki bean and its fractions. J. Food Lipids 2008, 15, 119-136. [CrossRef] 
38. Amarowicz, R.; Estrella, I.; Hernández, T.; Robredo, S.; Troszyńska, A.; Kosińska, A.; Pegg, R.B. Free radical-scavenging capacity, antioxidant activity, and phenolic composition of green lentil (Lens culinaris). Food Chem. 2010, 121, 705-711. [CrossRef]

39. Amarowicz, R.; Troszyńska, A.; Baryłko-Pikielna, N.; Shahidi, F. Polyphenolics extracts from legume seeds: Correlations between total antioxidant activity, total phenolics content, tannins content and astringency. J. Food Lipids 2004, 11, 278-286. [CrossRef]

40. Orak, H.H.; Karamać, M.; Amarowicz, R. Antioxidant activity of phenolic compounds of red bean (Phaseolus vulgaris L.). Oxid. Commun. 2015, 38, 67-76. 